\title{
Physicochemical quality, antioxidant capacity and nutritional value of edible flowers of some wild dahlia species
}

\author{
Esteban Arturo Rivera Espejel', Oscar Cruz Alvarez', \\ José Merced Mejía Muñoz, María del Rosario García Mateos ${ }^{1}$, \\ María Teresa Beryl Colinas León ${ }^{1}$, María Teresa Martínez Damián ${ }^{1 *}$
}

\author{
${ }^{1}$ Departmento de Fitotecnia \\ Universidad Autónoma Chapingo, Estado de Mexico, Mexico \\ ${ }^{2}$ Facultad de Ciencias Agrotecnológicas \\ Universidad Autónoma de Chihuahua, Chihuahua, Mexico
}

\begin{abstract}
Mexico is the centre of origin and domestication of the dahlia, which has the widest distribution worldwide as an ornamental plant; however, due to changes in eating habits in some sectors of the population (vegetarians and vegans), it has also been incorporated as an ingredient in the gastronomic field. The aim of this research was to determine the attributes of physicochemical quality, antioxidant capacity and nutritional value of ligulate flowers of some wild dahlia species. A completely randomized experimental design with five repetitions was used. Fresh weight, total titratable acidity (TTA), total soluble solids (TSS), ascorbic acid (AA), colour, total phenols (TP), total flavonoids (TFl), total anthocyanins (TAn), antioxidant capacity (AC) and proximate composition were evaluated. The highest fresh weight was observed in $D . \times$ hortorum, with similar values among its different flower colours. Likewise, D. merckii and D. coccinea stood out for their high TTA value; however, D. coccinea also had the highest AA content (0.77-0.9 $\left.\mathrm{mg} \mathrm{g}^{-1} \mathrm{FW}\right), \mathrm{TP}\left(12.87-19.92 \mathrm{mg} \mathrm{GAE} \mathrm{g}^{-1} \mathrm{FW}\right)$, TFl (6.78-11.32 mg QE g $\left.{ }^{-1} \mathrm{DW}\right)$ and AC (47.28-60.43 $\left.\mathrm{mg} \mathrm{AAEVC} \mathrm{g}^{-1} \mathrm{FW}\right)$. On the other hand, D. campanulata was notable for its high levels of moisture, fat and raw fibre; similarly, D. coccinea stood out for its high amounts of dry matter and total carbohydrates. The ligulate flowers of wild dahlias have a high concentration of bioactive compounds and a nutritional composition with beneficial contributions to health care, so they could be used for consumption as fresh products.
\end{abstract}

Key words: antioxidant capacity, floriphagia, functional food, non-traditional foods, plant genetic resources, post-harvest handling, vegans, vegetarians

\section{Abbreviations:}

TTA - total titratable acidity, TSS - total soluble solids, AA - ascorbic acid, AAEVC - Antioxidant Activity Equivalent to Vitamin C, TP - total phenols, TF1 - total flavonoids, TAn - total anthocyanins, AC - antioxidant capacity, ABTS - free radical-scavenging ability determined by the use of a stable 2,2'-azinobis(3-ethylbenzothiazoline-6-sulfonic acid) radical cation, $\mathrm{M}$ - moisture; DM - dry matter, $\mathrm{CP}$ - crude protein, $\mathrm{RF}$ - raw fat, $\mathrm{RFi}$ - raw fibre, TC - total carbohydrates, $\mathrm{A}$ - ash

*Corresponding author. 


\section{INTRODUCTION}

Flowers and inflorescences have constituted an important gastronomic element for many centuries for the civilizations of diverse regions around the world because there are innumerable reports in the literature that indicate their consumption. Among the species that can be mentioned are the rosebush (Rosa spp.), dandelion (Taraxacum officinale) and squash (Cucurbita spp.) in Europe and pre-Hispanic Mexico, but in countries such as China and India consumption of a greater variety of species is also indicated (Sotelo et al., 2007; Rop et al., 2012; Fernandes et al., 2018) At present, the search for new culinary experiences (shapes, colours and flavours) that provide attractive appearance and high nutritional value of the dishes (Mlcek and Rop, 2011) has allowed us to resume and broaden this culinary tradition.

One of the reasons for the increase in the consumption of edible flowers is associated with the presence of biologically active compounds that have beneficial effects on human health (Lee et al., 2009; Huang et al., 2014; Benvenuti et al., 2016) because they are widely valued by consumers seeking a healthy lifestyle (Yang et al., 2014; Chen and Wei, 2017). Among these compounds are phenolic acids, flavonoids and anthocyanins, which have antioxidant properties and, by inhibiting free radicals that induce oxidative stress, reduce the risk of chronic degenerative diseases (diabetes, cognitive deterioration and some types of cancer) and cardiovascular diseases, among others (Zeng et al., 2014; Loizzo et al., 2016; Pires et al., 2018). Edible flowers also have a variable concentration of fat, protein, vitamins, sugars and minerals, which makes them even more attractive for consumption as part of salads, or as decoration for gourmet dishes (Rop et al., 2012; Lara-Cortés et al., 2014).

On the other hand, the most visible problems of post-harvest handling of edible flowers and inflorescences are related to their high perishability due to their lack of photoassimilate accumulation organs, high sensitivity to ambient temperature and mechanical damage (Zeng et al., 2014; Ahmad and Tahir, 2016), as a result of which floral structures tend to undergo changes not only in their external appearance (colour and turgor), but also in their nutritional composition (phenolic compounds, flavonoids, vitamins) and their antioxidant capacity (Kaisoon et al., 2011; Gebremedhin et al., 2013; Liu et al., 2016) Therefore, studies of the variation in these compounds are of paramount importance for determining its magnitude and the possibility of implementing post-harvest conservation methods that allow maintaining and preserving the quality of flowers and inflorescences for use as food (Mlcek and Rop, 2011; Rachkeeree et al., 2018).

The dahlia is a plant native to Mexico. It is represented by 37 species in the genus Dhalia that belongs to the Asteraceae family. They produce flowers with a great diversity of colours (red, purple, pink, white and variegated) (Ohno et al., 2013; Ahmad and Tahir, 2016), and that is why they are cultivated mainly for the production of cut flowers, potted plants and elements for the design and construction of gardens (Younis et al., 2014). The flowers of dahlias also have nutritional and functional properties that make them suitable for consumption as food (Lara-Cortés et al., 2013; LaraCortés et al., 2016). However, there are very few or no references pertaining to this topic. Generation of relevant information will allow to expand the study, exploitation and rescue of wild dahlia species, whose natural diversity space is increasingly reduced and threatened by anthropogenic activities. That is why the objective of this research was to determine the attributes of physicochemical quality, antioxidant capacity and nutritional value of ligulate flowers of some wild dahlia species.

\section{MATERIAL AND METHODS}

\section{Plant material and location of the experiment}

The experiment was carried out in 2016 in the fruit and multipurpose laboratory of the Departamento de Fitotecnia at the Universidad Autónoma Chapingo (UACh). The plant material consisted of inflorescences formed by ligulate and tubular flowers (flower head) of 4 wild species (D. brevis, $D$. merckii, D. coccinea and D. campanulata) and 1 cultivated species $(D . \times$ hortorum) (control), which were harvested in August 2016 from the Experimental Agricultural Field "San Martin" (UACh) located at $19^{\circ} 29^{\prime} 23^{\prime \prime} \mathrm{N}$ and 98 53'37" $\mathrm{W}$, at an altitude of $2246 \mathrm{~m}$ and average annual temperature of $15.6^{\circ} \mathrm{C}$. The inflorescences were harvested when their stamens were exposed in the first row of tubular flowers of the flower head, and their stem was $25 \mathrm{~cm}$ long. They were placed in glass containers $(0.75 \mathrm{~L})$ with tap water for a period of 5 days at room temperature $\left(20 \pm 1^{\circ} \mathrm{C}\right)$. The ligules were separated from the flower head and classified according to colour; an SP $62^{\circledR}$ sphere colorimeter (X-Rite, Michigan, USA) was used to obtain the parameters of brightness $\left(\mathrm{L}^{*}\right)$, pitch angle $\left(\mathrm{h}^{\circ}\right)$ and purity of colour (chroma, $C^{*}$ ). On day 1 , they were 


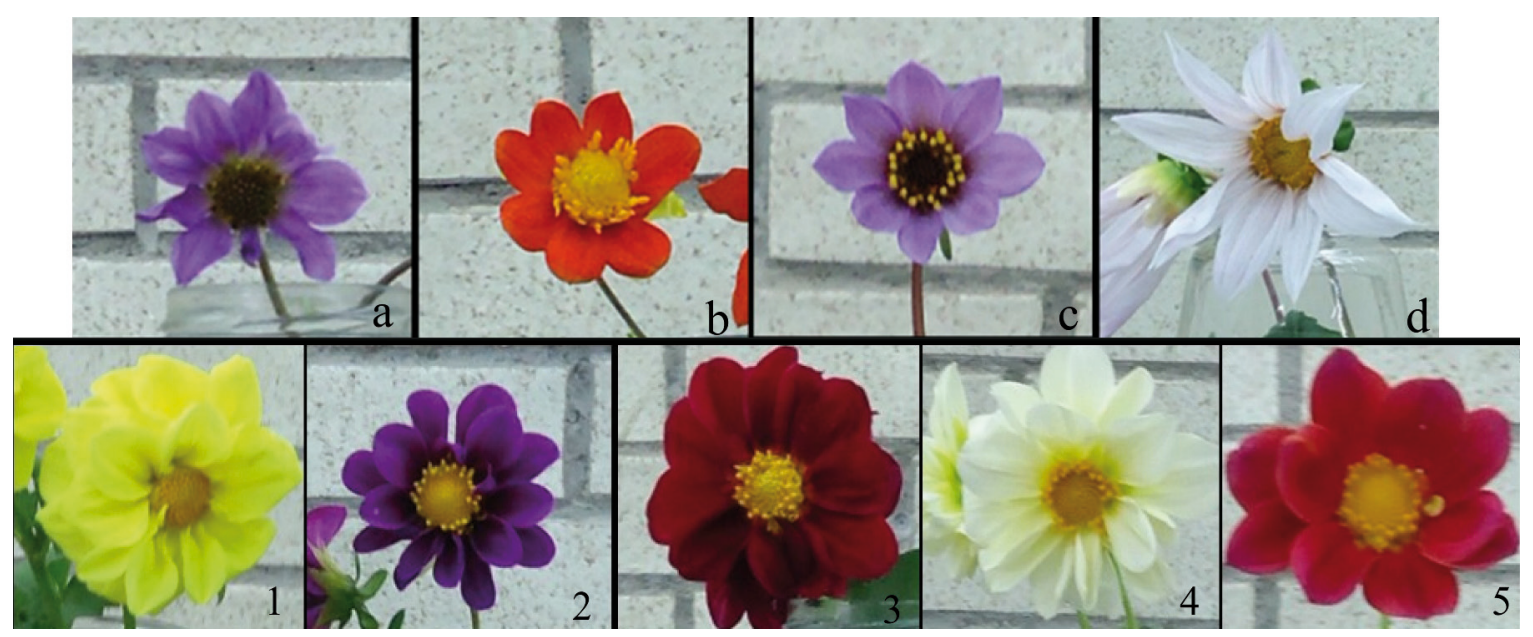

Figure 1. Colour of the ligulate flowers of wild dahlia species: a. D. brevis, b. D. coccinea, c. D. merckii, d. D. campanulata, and of the cultivated species of dahlia $D . \times$ hortorum (1-5)

as follows: D. brevis - violet ligules $\mathrm{L}^{*} 40.47, \mathrm{C}^{*}$ 33.21, $h^{\circ} 304.48$; D. merckii - violet L* 50.93, C* 27.75, $h^{\circ} 306$; D. coccinea - orange $\mathrm{L}^{*} 35.85, \mathrm{C}^{*}$ 63.49, $h^{\circ}$ 52.66; D. campanulata - white with light purple hue $\left.L^{*} 74.91, C^{*} 5.37, h^{\circ} 338.50\right)$, and the cultivated species $D . \times$ hortorum - cherry L* 10.46 , $C^{*}$ 20.18, $h^{\circ}$ 15.91; yellow L* 80.28, C* 93.79, $h^{\circ}$ 93.79; white $L^{*} 81.52, C^{*} 20.19, h^{\circ} 95$; purple $L^{*}$ 26.92, $C^{*} 45.09, h^{\circ} 332.92$; and red $L^{*} 24.55, C^{*}$ 39.56, $h^{\circ}$ 25.22) (Fig. 1).

\section{Crop management}

The multiplication and obtaining of the vegetal material began in the month of March of 2016 with the planting of the tuberous roots obtained in the previous growth cycle into boxes with peat (peat moss) in a greenhouse; their buds sprouted after 15 days. Transplanting into a field was performed in April 2016, where the distance between plants and rows was 0.6 and $1 \mathrm{~m}$, respectively. The supply of water and nutrients was carried out by means of a drip irrigation system 1-2 times per week, with an expenditure of 0.5-3.5 L per plant, depending on the ambient temperature, relative humidity and phenological stages of the crop. Fertilization was carried out based on the general NPK fertilizer ratio of 120-0-200, which was supplied in split doses to the transplants and before the beginning of flowering. Weed control and some crop management practices such as hilling were carried out manually.

\section{Experimental design}

A completely randomized experimental design with five repetitions was used, where the experimental unit consisted of a set of 3 containers $(0.75 \mathrm{~L})$ with
3 flowers with a $25 \mathrm{~cm}$ long stem. The evaluations were made on days 1, 3 and 5 (vase life).

\section{Parameters evaluated}

\section{Fresh weight}

The ligulate flowers were separated manually from the flower head and used to measure their weight with an EX125D analytical balance of the Explorer ${ }^{\circledR}$ Semi Micro Series (Ohaus, Parsippany, USA) with a maximum capacity and minimum reading of 51 and $0.01 \mathrm{~g}$, respectively. The results are expressed in $\mathrm{g}$.

\section{Total titratable acidity (TTA) and total soluble solids (TSS)}

The parameters TTA and TSS were obtained by macerating and obtaining juice from $1 \mathrm{~g}$ of ligulate flowers. For the determination of the percentage of citric acid (TTA), $5 \mathrm{~mL}$ of the juice were taken and neutralized with $0.1 \mathrm{~N} \mathrm{NaOH}$, using $1 \%$ phenolphthalein as indicator. TSS were quantified with a PAL- $1{ }^{\circledR}$ manual digital refractometer (Atago, Tokyo, Japan).

\section{Ascorbic acid (AA)}

The assay was carried out by the method described by Jagota and Dani (1982), with slight modifications. A $1 \mathrm{~g}$ sample was mixed with $5 \mathrm{~mL}$ of $10 \%$ trichloroacetic acid, homogenized and agitated vigorously for 5 minutes in the cold (ice), after which it was centrifuged for 5 minutes at $17,000 \mathrm{rpm}$ at $5^{\circ} \mathrm{C}$. Subsequently, a $400 \mu \mathrm{L}$ aliquot of the supernatant of each sample was taken and 2.2 $\mathrm{mL}$ of double-distilled? water and $400 \mu \mathrm{L}$ of $10 \%$ (v/v) Folin-Ciocalteu reagent were added to it. The mixture was stirred vigorously for 15 seconds and allowed to stand for 10 minutes; it was subsequently 
used to obtain the absorbance reading $(\lambda=760 \mathrm{~nm})$ using a Genesys $10-\mathrm{S}^{\mathrm{TM}}$ spectrophotometer (Thermo scientific, Florida, USA). The concentration was expressed in mg $100 \mathrm{~g}^{-1} \mathrm{FW}$ after calibration of a standard curve for ascorbic acid.

\section{Colour}

Its determination was made at the equatorial zone of the internal side of the ligulate flower by means of an SP62 ${ }^{\circledR}$ sphere colorimeter (X-Rite, Michigan, USA) to obtain the parameters of brightness $\left(\mathrm{L}^{*}\right)$, angle of tone $\left(\mathrm{h}^{\circ}\right)$ and the purity of the colour (chroma, $\mathrm{C}^{*}$ ).

\section{Phenolic compounds (TP)}

The determination of TP was carried out by the Folin-Ciocalteu method described by Waterman and Mole (1994), for which a $0.2 \mathrm{~g}$ sample was taken and mixed with $5 \mathrm{~mL}$ of $70 \%$ absolute ethyl alcohol $(\mathrm{v} / \mathrm{v})$; from this extract $50 \mu \mathrm{L}$ was taken, to which $7.950 \mathrm{~mL}$ of distilled water and $500 \mu \mathrm{L}$ of the Folin-Ciocalteu reagent $(2 \mathrm{~N})$ were added; the mixture was stirred and left to stand for 8 minutes. Subsequently, $1.5 \mathrm{~mL}$ of $20 \%$ (w:v) $\mathrm{Na}_{2} \mathrm{CO}_{3}$ was added, stirred and allowed to stand for $2 \mathrm{~h}$ under conditions of total darkness at room temperature $\left(22 \pm 1^{\circ} \mathrm{C}\right)$. The absorbance value $(\lambda=760 \mathrm{~nm})$ of the mixture was obtained with a Genesys $10-\mathrm{S}^{\mathrm{TM}}$ spectrophotometer (Thermo Scientific, Florida, USA). The concentration of total phenols was expressed as mg of gallic acid $\mathrm{g}^{-1} \mathrm{FW}$.

\section{Total flavonoids (TFl)}

The TFl were determined according to the method described by Loizzo et al. (2016), with slight modifications. A $1 \mathrm{~g}$ sample was taken and $5 \mathrm{~mL}$ of methanol was added; the mixture was homogenized and kept at room temperature until the methanol evaporated and the extract was dry. After taking $0.01 \mathrm{~g}$ of the dried extract, $5 \mathrm{~mL}$ of distilled water were added to it and stirred for 20 minutes. From that solution, $650 \mu \mathrm{l}$ was taken and $75 \mu \mathrm{L}$ of $\mathrm{NaNO}_{2}$ at $5 \%(\mathrm{v} / \mathrm{v})$ was added, giving it 6 minutes of agitation, followed by 6 minutes at rest. Next, $150 \mu \mathrm{L}$ of $\mathrm{AlCl}_{3}$ was added to a concentration of $10 \%$, giving it 4 minutes of agitation, followed by 5 minutes at rest; then $500 \mu \mathrm{L}$ of $\mathrm{NaOH}(1 \mathrm{M})$ and $1150 \mu \mathrm{L}$ of distilled water were added. Next, the absorbance reading $(\lambda=510 \mathrm{~nm})$ was taken with a Genesys $10-S^{\mathrm{TM}}$ spectrophotometer (Thermo scientific, Florida, USA). The concentration of total flavonoids was expressed as $\mathrm{mg}$ of quercetin $\mathrm{g}^{-1}$ of dry weight (DW).

\section{Total anthocyanins (TAn)}

The TAn concentration was determined with the differential $\mathrm{pH}$ method described by Giusti and Wrolstad (2011), for which a $0.2 \mathrm{~g}$ sample was taken and homogenized with $10 \mathrm{~mL}$ of $80 \%(\mathrm{v} / \mathrm{v})$ absolute ethyl alcohol. Subsequently, $800 \mu \mathrm{L}$ of the extract was taken separately, $3.2 \mathrm{~mL}$ of a buffer solution at $\mathrm{pH}=1(0.025 \mathrm{M} \mathrm{KCl})$ and $3.2 \mathrm{~mL}$ of a buffer solution at $\mathrm{pH}=4.5\left(0.4 \mathrm{M} \mathrm{CH}_{3} \mathrm{CO}_{2} \mathrm{Na}_{3} \mathrm{H}_{2} \mathrm{O}\right)$ were added to another sample. The absorbance readings of each mixture was taken at $\lambda=510$ and $700 \mathrm{~nm}$ in a Genesys $10-\mathrm{S}^{\mathrm{TM}}$ spectrophotometer (Thermo Scientific, Florida, USA). The total absorbance (At) of the sample was determined from the formula:

$$
\mathrm{At}=[(\mathrm{A} 510-\mathrm{A} 710) \mathrm{pH}=1.0]-[(\mathrm{A} 510-\mathrm{A} 700) \mathrm{pH}=4.5] .
$$

The concentration of total anthocyanins was calculated according to the formula:

$$
\mathrm{TAn}=\left[\frac{\mathrm{Ta} \times \mathrm{MW} \times \mathrm{DF} \times 1000}{\varepsilon \times 1}\right],
$$

where AT is total absorbance, $\mathrm{MW}=$ molecular weight of the molecular standard (cyanidin-3glucoside) (449.2 $\left.\mathrm{g} \mathrm{mol}^{-1}\right), \mathrm{DF}=$ dilution factor (1), $\varepsilon$ $=$ is the molar absorptivity coefficient from cyanidin3 -glucoside $(26,900)$. The results are expressed in $\mathrm{mg}$ of cyanidin-3-glucoside per $100 \mathrm{~g}^{-1} \mathrm{FW}$.

\section{Antioxidant capacity (AC)}

The determination of $\mathrm{AC}$ was carried out with the method employing ABTS [2,2-azino-bis (3-ethylbenzothiazolin-6-sulfonic acid)], modified by Ozgen et al. (2006), for which the radical ABTS $^{++}$was formed after the reaction of ABTS (7 $\mathrm{mM})$ with potassium persulfate $(2.45 \mathrm{mM}$, final concentration) incubated at room temperature and in the dark for 16 hours. After the radical ABTS $^{++}$was formed, it was diluted with PBS (phosphate buffer solution) ( $\mathrm{pH}$ 7.4) until a value of absorbance from $0.7 \pm 0.1$ to $734 \mathrm{~nm}$ (maximum absorption length). For the assay, $3.98 \mathrm{~mL}$ of the $\mathrm{ABTS}^{++}$solution and $20 \mu \mathrm{L}$ of the sample extract were mixed, and allowed to stand for 2 hours; the absorbance reading was taken at $\lambda=734 \mathrm{~nm}$. The results are expressed in AAEVC (Antioxidant Activity Equivalent to Vitamin C).

\section{Proximate composition}

The standard AOAC methods were used to determine moisture, dry matter, crude protein, raw fat, raw fibre, total carbohydrates and ash (AOAC, 1990). 


\section{Statistical analysis}

For the analysis of the data, analyses of variance (ANOVA) and the Tukey multiple comparison of means $(p \leq 0.05)$ were performed, for which the statistical program SAS version 9.0 was used.

\section{RESULTS AND DISCUSSION}

\section{Physicochemical quality}

The results of fresh weight and titratable acidity are shown in Table 1. On day 1, after cutting the flowers, it was observed that the ligulate cherry, yellow, and white flowers of $D . \times$ hortorum had the highest values of fresh weight, with 1.6, 1.54 and $1.75 \mathrm{~g}$, respectively; however, these values were not statistically significantly different from what was shown by the red ligules $(1.29 \mathrm{~g})$ of the same species. On day 3, the cherry and white ligules stood out the most, with a tendency to increase the weight values, while on the fifth day this behaviour was reversed and those with greater weights were the cherry, yellow, and white ligules. Similar results have been reported in several other species such as Iris versicolor (Ahmad and Tahir, 2016), Gerbera jamesonii (Babarabie et al., 2016), Lilium spp., and Rosa hybrid (Ren et al., 2017).

The accumulation of citric acid on day 1 was higher for $D$. brevis, D. merckii and D. coccinea (1.4, 1.2 and $1.3 \%$, respectively), however, on day 3 , it decreased to 0.7 and $0.9 \%$ (D. merckii and $D$. coccinea), increasing again on day 5 to 2.7 and $3.1 \%$, while the lowest values were present in $D . \times$ hortorum in the yellow, white and cherry ligules. In this regard, Ahmad and Tahir (2016) indicate that cut flowers have a temporary variation in their fresh weight due to the opening of the floral bud; however, this fresh weight decreases as translocation of nutrients from other organs occurs (leaves and stems), which concludes with senescence (Ren et al., 2017), since, according to Lara-Cortés et al. (2016) and Azuma et al. (2019), dahlia inflorescences do not show sensitivity to the presence of external ethylene.

On the other hand, Gebremedhin et al. (2013) and Azuma et al. (2019) indicate that the low concentration of soluble carbohydrates that can be used as cellular respiration substrate prevent maintaining the integrity of the membrane, cell wall and synthesis of pigments, which makes it difficult to maintain life in a vase of cut flowers. In this sense, the TSS concentration fluctuated between 0.06 and $0.24{ }^{\circ}$ Brix, with the highest values in the ligulate flowers (cherry, yellow and white) of $D . \times$ hortorum, in which the trend was similar to that observed in fresh weight and TTA, where the wild species did not show significant values (Tab. 2). Similar results had been reported in Gerbera jamesonii flowers (Babarabie et al., 2016) and in the 'Red Sky' and 'Blizzard' varieties of rosebush (Gebremedhin et al., 2013).

Among the nutritional components present in the ligulate flowers of dahlia, there was ascorbic acid, which was higher in $D$. coccinea, with values of $0.9,0.77$ and $0.89 \mathrm{mg} \mathrm{g}^{-1} \mathrm{FW}$, and the lowest in $D$. brevis and D. merckii, with 0.31 and $0.300 \mathrm{mg} \mathrm{g}^{-1}$ FW on day 1; however, on days 3 and 5 the lowest contents were in D. merckii (0.19 and $0.25 \mathrm{mg} \mathrm{g}^{-1}$ FW, respectively) and $D . \times$ hortorum with purple ligules $\left(0.20\right.$ and $0.21 \mathrm{mg} \mathrm{g}^{-1} \mathrm{FW}$, respectively). These results exceed $0.5 \mu \mathrm{g}$ of ascorbic acid $\mathrm{g}^{-1}$ of ligule indicated by Lara-Cortés et al. (2014) for different varieties and colours of dahlia, in which

Table 1. Changes in mean values of fresh weight and titratable acidity of ligulate flowers of some wild dahlia species

\begin{tabular}{|c|c|c|c|c|c|c|}
\hline \multirow[t]{2}{*}{ Species } & \multicolumn{3}{|c|}{$\begin{array}{l}\text { Fresh weight } \\
(\mathrm{g})\end{array}$} & \multicolumn{3}{|c|}{$\begin{array}{l}\text { Titratable acidity } \\
\text { (\% citric acid })\end{array}$} \\
\hline & Day 1 & Day 3 & Day 5 & Day 1 & Day 3 & Day 5 \\
\hline D. brevis & $0.23 \mathrm{~d}^{*}$ & $0.31 \mathrm{e}$ & $0.09 \mathrm{~d}$ & $1.4 \mathrm{a}$ & $0.6 \mathrm{~b}-\mathrm{d}$ & $2.9 \mathrm{a}$ \\
\hline D. merckii & $0.17 \mathrm{~d}$ & $0.22 \mathrm{e}$ & $0.10 \mathrm{~d}$ & $1.2 \mathrm{a}$ & $0.7 \mathrm{ab}$ & $2.7 \mathrm{a}$ \\
\hline D. coccinea & $0.19 \mathrm{~d}$ & $0.26 \mathrm{e}$ & $0.08 \mathrm{~d}$ & $1.3 \mathrm{a}$ & $0.9 \mathrm{a}$ & $3.1 \mathrm{a}$ \\
\hline D. campanulata & $0.67 \mathrm{~cd}$ & $0.85 \mathrm{~d}$ & $0.41 \mathrm{~cd}$ & $0.6 \mathrm{bc}$ & $0.4 \mathrm{~d}$ & $1.4 \mathrm{~b}$ \\
\hline \multicolumn{7}{|l|}{ D. $\times$ hortorum } \\
\hline Cherry & $1.6 \mathrm{a}$ & $2.01 \mathrm{ab}$ & $1.98 \mathrm{a}$ & $0.7 \mathrm{bc}$ & $0.5 \mathrm{~b}-\mathrm{d}$ & $0.6 \mathrm{c}$ \\
\hline Yellow & $1.54 \mathrm{a}$ & $1.76 \mathrm{bc}$ & $1.51 \mathrm{ab}$ & $0.4 \mathrm{c}$ & $0.5 \mathrm{~b}-\mathrm{d}$ & $0.7 \mathrm{bc}$ \\
\hline White & $1.75 \mathrm{a}$ & $2.28 \mathrm{a}$ & $1.78 \mathrm{a}$ & $0.6 \mathrm{bc}$ & $0.4 \mathrm{~d}$ & $1.1 \mathrm{bc}$ \\
\hline Purple & $0.85 \mathrm{bc}$ & $1.01 \mathrm{~d}$ & $0.64 \mathrm{~cd}$ & $0.8 \mathrm{~b}$ & $0.7 \mathrm{a}-\mathrm{c}$ & $0.8 \mathrm{bc}$ \\
\hline Red & $1.29 \mathrm{ab}$ & $1.65 \mathrm{c}$ & $0.99 \mathrm{bc}$ & $0.6 \mathrm{bc}$ & $0.5 \mathrm{~cd}$ & $0.8 \mathrm{bc}$ \\
\hline
\end{tabular}

*Values with the same letter within a column are not statistically different according to the Tukey test $(p \leq 0.05)$ 
Table 2. Total soluble solids and ascorbic acid contents in ligulate flowers of some wild dahlia species

\begin{tabular}{|c|c|c|c|c|c|c|}
\hline \multirow[t]{2}{*}{ Species } & \multicolumn{3}{|c|}{$\begin{array}{l}\text { Total soluble solids } \\
\left({ }^{\circ} \text { Brix }\right)\end{array}$} & \multicolumn{3}{|c|}{$\begin{array}{c}\text { Ascorbic acid } \\
\left(\mathrm{mg} \mathrm{g}^{-1} \mathrm{FW}\right)\end{array}$} \\
\hline & Day 1 & Day 3 & Day 5 & Day 1 & Day 3 & Day 5 \\
\hline D. brevis & $0.10 \mathrm{~b}$ & $0.12 \mathrm{~b}$ & $0.06 \mathrm{~b}$ & $0.31 \mathrm{ef}$ & $0.26 \mathrm{e}$ & $0.27 \mathrm{f}$ \\
\hline D. merckii & $0.10 \mathrm{~b}$ & $0.10 \mathrm{~b}$ & $0.08 \mathrm{ab}$ & $0.30 \mathrm{f}$ & $0.19 \mathrm{f}$ & $0.25 \mathrm{fg}$ \\
\hline D. coccinea & $0.14 \mathrm{ab}$ & $0.16 \mathrm{ab}$ & $0.12 a b$ & $0.90 \mathrm{a}$ & $0.77 \mathrm{a}$ & $0.89 \mathrm{a}$ \\
\hline D. campanulata & $0.10 \mathrm{~b}$ & $0.16 \mathrm{ab}$ & $0.10 a b$ & $0.40 \mathrm{~d}$ & $0.36 \mathrm{~d}$ & $0.39 \mathrm{de}$ \\
\hline \multicolumn{7}{|l|}{ D. $\times$ hortorum } \\
\hline Cherry & $0.20 \mathrm{a}$ & $0.16 \mathrm{ab}$ & $0.10 a b$ & $0.61 \mathrm{~b}$ & $0.42 \mathrm{~b}$ & $0.49 \mathrm{~b}$ \\
\hline Yellow & $0.20 \mathrm{a}$ & $0.24 \mathrm{a}$ & $0.14 \mathrm{a}$ & $0.43 \mathrm{~d}$ & $0.37 \mathrm{~cd}$ & $0.42 \mathrm{~cd}$ \\
\hline White & $0.14 \mathrm{ab}$ & $0.24 \mathrm{a}$ & $0.10 \mathrm{ab}$ & $0.34 \mathrm{e}$ & $0.33 \mathrm{~d}$ & $0.36 \mathrm{e}$ \\
\hline Purple & $0.18 \mathrm{a}$ & $0.10 \mathrm{~b}$ & $0.06 \mathrm{~b}$ & $0.22 \mathrm{~g}$ & $0.20 \mathrm{f}$ & $0.21 \mathrm{~g}$ \\
\hline Red & $0.20 \mathrm{a}$ & $0.18 a b$ & $0.10 \mathrm{ab}$ & $0.48 \mathrm{c}$ & $0.41 \mathrm{bc}$ & $0.47 \mathrm{bc}$ \\
\hline
\end{tabular}

*Values with the same letter within a column are not statistically different according to the Tukey test $(p \leq 0.05)$

the variation is determined by the balance between biosynthesis and degradation, as well as between reduction and oxidation (Huang et al., 2014), which is part of the role played by this vitamin as a watersoluble antioxidant and the conditions in which the plant or organ develops post-harvest (Liu et al., 2016).

The colour of the floral structures constitutes one of the most important characteristics with respect to the post-harvest handling of cut flowers (Zhang et al., 2015). In this work, the colour brilliance ( $\left.\mathrm{L}^{*}\right)$ was greater for $D . \times$ hortorum with yellow flowers (80.28, 84.49 and 87.52) and white flowers (81.52, 82.47 and 89.11) (Tab. 3), while those of cherry colour showed the lowest brightness (10.46, 22.29 and 16.12), which is associated with the absorption of a greater range of wavelengths of light, given its darker appearance, since, according to Arellano et al. (2015), low values of the $L^{*}$ component contribute to the visualization of darker colours and a high concentration of secondary pigments (anthocyanins and carotenoids) (Chen and Wei, 2017).

In the evaluation period, the yellow flowers showed greater purity of colour $\left(\mathrm{C}^{*}\right)$ in $D . \times$ hortorum $(93.79,90.47$ and 94.24$)$, followed by $D$. coccinea $(63.49,70.64$ and 55.61), with lower values observed in D. campanulata (Tab. 3). Younis et al. (2014), when analysing varieties with different colours, had found that the clear varieties (white) showed the highest $\mathrm{L}^{*}$ values and the lowest $\mathrm{C}^{*}$ values, which agrees with the results obtained in this research. On the other hand, higher values of $\mathrm{C}^{*}$ are usually more attractive to the human eye (Yang et al., 2014).
D. campanulata had ligulate flowers with the highest colour tonality $\left(\mathrm{h}^{\circ}\right)$, with values of 338.50 , 345.46 and 350.74 , followed by $D . \times$ hortorum with purple flowers $(332.92,333.63$ and 318.92), and the lowest values in $D . \times$ hortorum with red flowers (25.22, 33.04 and 32.34). The variability with respect to colour tonality can be explained by the same colour differences in each species analysed as a result of the concentration of secondary pigments, as indicated for flowers of 10 species of Rhododendron (Liu et al., 2016). Likewise, it is important to point out that colour is one of the most important factors in the selection and use of flowers as food (Lee et al., 2009; Lara-Cortés et al., 2016) and its conservation is influenced by a great diversity of factors, among them the genotype and the management conditions postharvest (Ren et al., 2017). However, a low concentration of carbohydrates can accelerate the degradation of pigments and contribute to discoloration in cut flowers (Li et al., 2015; Azuma et al., 2019).

D. coccinea showed statistically the highest values of TP $\left(15.29,12.87,19.92 \mathrm{mg}^{\mathrm{GAE}} \mathrm{g}^{-1}\right.$ FW); however, on day 5 , cherry and yellow ligules (D. $\times$ hortorum) were similar, with 7.29 and 7.82 mg GAE $\mathrm{g}^{-1} \mathrm{FW}$, respectively (Tab 4). A similar behaviour had been observed by Ahmad and Tahir (2016) in flowers of the genus Iris (I. germanica and I. kashmiriana), which the authors associate with failures in the redistribution of these compounds between organs, as well as the increase in their synthesis as a mechanism of defence to delay senescence, given the ability of these compounds to inhibit the activity of free radicals (Zeng et al., 2014). 
Table 3. Colour components of ligulate flowers of some wild dahlia species

\begin{tabular}{|c|c|c|c|}
\hline \multirow[t]{2}{*}{ Species } & Day 1 & Day 3 & Day 5 \\
\hline & \multicolumn{3}{|c|}{ Brightness $\left(L^{*}\right)$} \\
\hline D. brevis & $40.47 \mathrm{~d}^{*}$ & $55.86 \mathrm{~d}$ & $51.18 \mathrm{c}$ \\
\hline D. merckii & $50.93 \mathrm{c}$ & $60.64 \mathrm{c}$ & $54.44 \mathrm{c}$ \\
\hline D. coccinea & $35.85 \mathrm{e}$ & $46.07 \mathrm{e}$ & $42.42 \mathrm{~d}$ \\
\hline D. campanulata & $74.91 \mathrm{~b}$ & $76.47 \mathrm{~b}$ & $73.29 \mathrm{~b}$ \\
\hline \multicolumn{4}{|l|}{ D. $\times$ hortorum } \\
\hline Cherry & $10.46 \mathrm{~g}$ & $22.29 \mathrm{~g}$ & $16.12 \mathrm{f}$ \\
\hline Yellow & $80.28 \mathrm{a}$ & 84.49 a & $87.52 \mathrm{a}$ \\
\hline White & $81.52 \mathrm{a}$ & $82.47 \mathrm{a}$ & $89.11 \mathrm{a}$ \\
\hline Purple & $26.92 \mathrm{f}$ & $27.11 \mathrm{f}$ & $29.15 \mathrm{e}$ \\
\hline \multirow[t]{2}{*}{ Red } & $24.55 \mathrm{f}$ & $27.12 \mathrm{f}$ & $29.46 \mathrm{e}$ \\
\hline & \multicolumn{3}{|c|}{ Purity $\left(\mathrm{C}^{*}\right)$} \\
\hline D. brevis & $33.21 \mathrm{~d}$ & $28.27 \mathrm{~d}$ & $19.70 \mathrm{e}$ \\
\hline D. merckii & $27.75 \mathrm{~d}$ & $18.31 \mathrm{e}$ & $16.86 \mathrm{e}$ \\
\hline D. coccinea & $63.49 \mathrm{~b}$ & $70.64 \mathrm{~b}$ & $55.61 \mathrm{~b}$ \\
\hline D. campanulata & $5.37 \mathrm{f}$ & $5.92 \mathrm{f}$ & $5.05 \mathrm{f}$ \\
\hline \multicolumn{4}{|l|}{ D. $\times$ hortorum } \\
\hline Cherry & $20.18 \mathrm{e}$ & $42.55 \mathrm{c}$ & $35.34 \mathrm{~d}$ \\
\hline Yellow & $93.79 \mathrm{a}$ & $90.47 \mathrm{a}$ & $94.24 \mathrm{a}$ \\
\hline White & $20.19 \mathrm{e}$ & $15.96 \mathrm{e}$ & $16.76 \mathrm{e}$ \\
\hline Purple & $45.09 \mathrm{c}$ & $40.94 \mathrm{c}$ & $44.86 \mathrm{c}$ \\
\hline \multirow[t]{2}{*}{ Red } & $39.56 \mathrm{c}$ & $41.09 \mathrm{c}$ & $48.49 \mathrm{c}$ \\
\hline & \multicolumn{3}{|c|}{ Tonality $\left(\mathrm{h}^{\circ}\right)$} \\
\hline D. brevis & $304.48 \mathrm{c}$ & $314.05 \mathrm{c}$ & $307.21 \mathrm{c}$ \\
\hline D. merckii & $306.00 \mathrm{c}$ & $315.30 \mathrm{c}$ & $310.37 \mathrm{c}$ \\
\hline D. coccinea & $52.66 \mathrm{e}$ & $53.95 \mathrm{e}$ & $61.28 \mathrm{f}$ \\
\hline D. campanulata & $338.50 \mathrm{a}$ & $345.46 \mathrm{a}$ & $350.74 \mathrm{a}$ \\
\hline \multicolumn{4}{|l|}{ D. $\times$ hortorum } \\
\hline Cherry & $15.91 \mathrm{~g}$ & $20.56 \mathrm{~g}$ & $22.05 \mathrm{~h}$ \\
\hline Yellow & $93.79 \mathrm{~d}$ & $96.72 \mathrm{~d}$ & $94.72 \mathrm{e}$ \\
\hline White & $95.00 \mathrm{~d}$ & $97.85 \mathrm{~d}$ & $100.07 \mathrm{~d}$ \\
\hline Purple & $332.92 \mathrm{~b}$ & $333.63 \mathrm{~b}$ & $318.92 b$ \\
\hline Red & $25.22 \mathrm{f}$ & $33.04 \mathrm{f}$ & $32.34 \mathrm{~g}$ \\
\hline
\end{tabular}

*Values with the same letter within a column are not statistically different according to the Tukey test $(p \leq 0.05)$

The TP observed in D. coccinea was lower than that observed by Navarro-González et al. (2015) in orange flowers of Tagetes erecta (26.63 mg GAE $\mathrm{g}^{-1}$ FW). Orange flowers of Tropaeolum majus are reported with a higher concentration of TP $(907.05$ $\left.\pm 10.36 \mathrm{mg} \mathrm{GAE}^{-1} \mathrm{FW}\right)$ than the red and yellow flowers (799.35 \pm 10.77 and $442.02 \pm 5.09 \mathrm{mg}$ GAE $\mathrm{g}^{-1} \mathrm{FW}$, respectively) (Arellano et al., 2015). For their part, Lara-Cortés et al. (2014) indicate values of $127.5 \mathrm{mg} \mathrm{GAE} \mathrm{g}^{-1} \mathrm{FW}$ for dahlia with purple flowers, in addition to gallic acid and caffeic acid as the compounds responsible for this concentration, because species such as $D$. mignon show higher concentrations of chlorogenic acid (Pires et al., 2018). Likewise, mean values between 2.53 and 5.11 $\mathrm{g}$ of gallic acid per $\mathrm{kg}$ of fresh weight are reported by Rop et al. (2012) for 12 species with edible flowers, among them, Dianthus caryophyllus, Tagetes patula, Rosa odorata, Fuchsia $\times$ hybrida and Viola $\times$ wittrockiana.

During the evaluation period, the highest concentration of TFl was observed in the wild species $D$. coccinea $(8.15,6.78$ and $11.32 \mathrm{mg}$ QE $\left.\mathrm{g}^{-1} \mathrm{DW}\right)$, followed by $D . \times$ hortorum with cherry and yellow flowers (Tab 4). These results are comparable to those reported in edible flowers of 
Table 4. Changes in the concentration of total phenols and total flavonoids in ligulate flowers of some wild dahlia species

\begin{tabular}{|c|c|c|c|c|c|c|}
\hline \multirow[t]{2}{*}{$\overline{\text { Species }}$} & \multicolumn{3}{|c|}{$\begin{array}{c}\text { Total phenols } \\
\left.\text { (mg GAE g }{ }^{-1} \mathrm{FW}\right)\end{array}$} & \multicolumn{3}{|c|}{$\begin{array}{l}\text { Total flavonoids } \\
\left(\mathrm{mg} \mathrm{QE} \mathrm{g}^{-1} \mathrm{FW}\right)\end{array}$} \\
\hline & Day 1 & Day 3 & Day 5 & Day 1 & Day 3 & Day 5 \\
\hline D. brevis & $11.91 \mathrm{c}^{*}$ & $7.26 \mathrm{c}$ & $10.23 \mathrm{f}$ & $1.82 \mathrm{~cd}$ & $1.23 \mathrm{ef}$ & $1.72 \mathrm{~d}$ \\
\hline D. merckii & $10.60 \mathrm{de}$ & $7.02 \mathrm{c}$ & $8.03 \mathrm{~g}$ & $1.03 \mathrm{~d}$ & $0.69 \mathrm{f}$ & $0.90 \mathrm{e}$ \\
\hline D. coccinea & $15.29 \mathrm{a}$ & $12.87 \mathrm{a}$ & $19.92 \mathrm{a}$ & $8.15 \mathrm{a}$ & $6.78 \mathrm{a}$ & $11.32 \mathrm{a}$ \\
\hline D. campanulata & $1.66 \mathrm{~g}$ & $1.25 \mathrm{~d}$ & $2.55 \mathrm{~h}$ & $1.02 \mathrm{~d}$ & $0.76 \mathrm{f}$ & $1.47 \mathrm{de}$ \\
\hline \multicolumn{7}{|l|}{ D. $\times$ hortorum } \\
\hline Cherry & $12.06 \mathrm{bc}$ & $10.77 \mathrm{~b}$ & $11.70 \mathrm{~cd}$ & $7.29 \mathrm{a}$ & $5.18 \mathrm{~b}$ & $7.17 \mathrm{~b}$ \\
\hline Yellow & $9.81 \mathrm{e}$ & $9.93 \mathrm{~b}$ & $12.36 \mathrm{c}$ & $7.82 \mathrm{a}$ & $6.23 \mathrm{a}$ & $7.52 \mathrm{~b}$ \\
\hline White & $6.98 \mathrm{f}$ & $7.08 \mathrm{c}$ & 10.36 ef & $1.90 \mathrm{~cd}$ & $1.81 \mathrm{de}$ & $2.04 \mathrm{~d}$ \\
\hline Purple & $13.11 \mathrm{~b}$ & $12.02 \mathrm{a}$ & $13.94 \mathrm{~b}$ & $2.00 \mathrm{~cd}$ & $1.94 \mathrm{~d}$ & $2.08 \mathrm{~d}$ \\
\hline Red & $11.41 \mathrm{~cd}$ & $7.10 \mathrm{c}$ & $11.02 \mathrm{de}$ & $4.21 \mathrm{~b}$ & $4.12 \mathrm{c}$ & $4.55 \mathrm{c}$ \\
\hline
\end{tabular}

*Values with the same letter within a column are not statistically different according to the Tukey test $(p \leq 0.05)$

Capparis spinosa and Hedysarum coronarium (5.8 and $8.0 \mathrm{mg} \mathrm{QE} \mathrm{g}^{-1}$ of dry extract, respectively), but lower than those of Sambucus nigra (23.6 $\mathrm{mg} \mathrm{QE} \mathrm{g}^{-1}$ dry extract) indicated by Loizzo et al. (2016), who also found that routine and quercetin were the main flavonoids. The higher concentration of flavonoids in D. coccinea, whose flowers are orange, confirms that the colour orange is related to the presence of flavonoids (Garzón et al., 2015), as does the yellow colour of the flowers of different edible plants (Liu et al., 2016). Similarly, it is important to note that D. coccinea showed a significant increase in the TFl value at the end of the evaluation, which may be associated with the presence of specific flavonoids (quercetin, naringenin, butein and apigenin) in the dahlia petals (Lara-Cortés et al., 2014; Pires et al., 2018), given their ability to eliminate reactive oxygen species as a response to the beginning of the senescence process, as described by Zhao et al. (2012) in flowers of three cultivars of Paeonia lactiflora.

As can be seen in Table 5, the cultivated species $(D . \times$ hortorum $)$ of cherry colour showed the highest concentration of TAn (14.74, 12.03 and $11.97 \mathrm{mg}$ of cyanidin-3-glucoside $100 \mathrm{~g}^{-1} \mathrm{FW}$ ). These results were lower than those reported by Garzón et al. (2015) in orange and red flowers of Tropaeolum majus (108.8 and $168.0 \mathrm{mg}$ of cyanidin-3-glucoside $100 \mathrm{~g}^{-1} \mathrm{FW}$, respectively); however, they are similar to those obtained by Benvenuti et al. (2016) in red flowers of Dianthus $\times$ barbatus, Pelargonium peltatum and Viola $\times$ wittrockiana $(13.3,12.5$ and $12.4 \mathrm{mg}$ cyanidin-3glucoside $100 \mathrm{~g}^{-1} \mathrm{FW}$, respectively). Lara-Cortés et

Table 5. Changes in the concentration of total anthocyanins and antioxidant capacity in ligulate flowers of some wild species of dahlia

\begin{tabular}{|c|c|c|c|c|c|c|}
\hline \multirow[t]{2}{*}{ Species } & \multicolumn{3}{|c|}{$\begin{array}{c}\text { Total anthocyanins } \\
\text { (mg of cyanidin-3-glucoside } 100 \mathrm{~g}^{-1} \mathrm{FW} \text { ) }\end{array}$} & \multicolumn{3}{|c|}{$\begin{array}{l}\text { Antioxidant capacity } \\
\left(\mathrm{mg} \text { AAEVC } \mathrm{g}^{-1} \mathrm{FW}\right)\end{array}$} \\
\hline & Day 1 & Day 3 & Day 5 & Day 1 & Day 3 & Day 5 \\
\hline D. brevis & $2.24 \mathrm{~d}^{*}$ & $1.87 \mathrm{~d}$ & $2.11 \mathrm{~d}$ & $16.10 \mathrm{e}$ & $13.72 \mathrm{~d}$ & $15.01 \mathrm{e}$ \\
\hline D. merckii & $1.66 \mathrm{e}$ & $1.53 \mathrm{~d}$ & $1.78 \mathrm{de}$ & $15.46 \mathrm{e}$ & $13.50 \mathrm{~d}$ & $15.54 \mathrm{e}$ \\
\hline D. coccinea & $1.31 \mathrm{f}$ & $1.17 \mathrm{e}$ & $1.52 \mathrm{e}$ & $57.32 \mathrm{a}$ & $47.28 \mathrm{a}$ & $60.43 \mathrm{a}$ \\
\hline D. campanulata & $0.26 \mathrm{~g}$ & $0.24 \mathrm{f}$ & $0.43 \mathrm{f}$ & $7.24 \mathrm{f}$ & $6.82 \mathrm{e}$ & $11.79 \mathrm{f}$ \\
\hline \multicolumn{7}{|l|}{ D. $\times$ hortorum } \\
\hline Cherry & $14.74 \mathrm{a}$ & $12.03 \mathrm{a}$ & $11.97 \mathrm{a}$ & $22.97 \mathrm{c}$ & $18.00 \mathrm{c}$ & $21.89 \mathrm{~d}$ \\
\hline Yellow & $0.24 \mathrm{~g}$ & $0.11 \mathrm{f}$ & $0.10 \mathrm{fg}$ & $20.86 \mathrm{~cd}$ & $18.24 \mathrm{c}$ & $22.77 \mathrm{~cd}$ \\
\hline White & $0.09 \mathrm{~g}$ & $0.07 \mathrm{f}$ & $0.06 \mathrm{~g}$ & $15.11 \mathrm{e}$ & $13.60 \mathrm{~d}$ & $15.60 \mathrm{e}$ \\
\hline Purple & $5.17 \mathrm{~b}$ & $4.94 \mathrm{~b}$ & $5.02 \mathrm{~b}$ & $19.97 \mathrm{~d}$ & $18.59 \mathrm{c}$ & $23.08 \mathrm{c}$ \\
\hline Red & $4.01 \mathrm{c}$ & $3.66 \mathrm{c}$ & $4.02 \mathrm{c}$ & $34.99 \mathrm{~b}$ & $22.75 \mathrm{~b}$ & $39.68 \mathrm{~b}$ \\
\hline
\end{tabular}

*Values with the same letter within a column are not statistically different according to the Tukey test $(p \leq 0.05)$ 
al. (2014) found the highest concentration of total anthocyanins in purple dahlia flowers $(257.5 \mathrm{mg}$ $100 \mathrm{~g}^{-1} \mathrm{FW}$ ), while the white and yellow flowers had the lowest content, which is consistent with the results obtained in this research, where the flowers of more intense colour registered higher concentrations of anthocyanins than the white or clear flowers. In this sense, Yamaguchi et al. (1999) indicate a higher concentration of anthocyanins in pink, orange, red and purple colours, in contrast to yellows and whites, where they were not detected, according to these authors, the concentration of anthocyanins determined the colour intensity of the flowers. The concentration of anthocyanins can be affected by different factors such as stress due to environmental conditions, genetic aspects, variety and agronomic management (Lee et al., 2009). In addition, the concentration of total anthocyanins varies throughout the flowering stages (LaraCortés et al., 2013).

The wild species $D$. coccinea stands out for its high AC (57.32, 47.28 and $60.43 \mathrm{mg}$ AAEVC $\mathrm{g}^{-1} \mathrm{FW}$ ), followed by the cultivated species $D$. $\times$ hortorum with red flowers $(34.99,22.75$ and 39.68 mg AAEVC $\mathrm{g}^{-1} \mathrm{FW}$ ) (Tab. 5). The behaviour observed in $D$. coccinea (orange flowers), agrees with the results obtained by Benvenuti et al. (2016), who found greater antioxidant activity in the flowers of Tagetes erecta $(70.42 \mathrm{mmol}$ $\mathrm{FeSO}_{4} 100 \mathrm{~g}^{-1} \mathrm{FW}$ ), followed by the red flowers of Fuchsia hybrida, Dianthus $\times$ barbatus, Viola $\times$ wittrockiana and Pelargonium peltatum (47.52, 38.67, 36.55 and $34.78 \mathrm{mmol} \mathrm{FeSO}_{4} 100 \mathrm{~g}^{-1} \mathrm{FW}$, respectively). Similarly, Arellano et al. (2015) reported the highest antioxidant capacity in orange flowers of T. majus (DPPH: $3928.226 \mu \mathrm{M} \mathrm{TE} \mathrm{g}^{-1}$
DW, ABTS: $622.92 \mu \mathrm{M}$ TE $\mathrm{g}^{-1}$ dry sample) in relation to red and yellow flowers.

On the other hand, the lowest values of $\mathrm{AC}$ are for D. campanulata $(7.24,6.82$ and $11.79 \mathrm{mg}$ AAEVC $\mathrm{g}^{-1} \mathrm{FW}$ ), results that are similar to those reported by Rop et al. (2012) in edible flowers of 12 plant species (4.21 to $6.96 \mathrm{~g} \mathrm{VEAC} \mathrm{kg}^{-1} \mathrm{FW}$ ). In this sense, the colour of the flowers is related to $\mathrm{AC}$ in such a way that intense colours (red and blue) are good indicators of this parameter, unlike the white colour that is associated with low values (Benvenuti et al., 2016). Besides, AC can be influenced differently by the phytochemicals present in flowers, so that a high antioxidant capacity can be mainly due to flavonoids or carotenoids, instead of anthocyanins (Chen and Wei, 2017).

\section{Nutritional value}

The data resulting from the analysis of the proximate composition are shown in Table 6 . Among the wild species, with the exception of D. campanulata $(93.4 \%)$, the moisture content did not exceed $90 \%$, where $D$. coccinea was the lowest in moisture but the highest in DM - a result that confirms the correlation between M and DM. It was a behaviour that agrees with that obtained by LaraCortés et al. (2014) in dahlia flowers (88 to 92\%), as well as with the data obtained in edible flowers of T. majus, Tagetes erecta and Spilanthes oleracea (89.3, 83.4 and 81.7\%, respectively) (NavarroGonzález et al., 2015), in which it is important to point out that the accumulation of DM is associated with the nutritional contribution during the growth and development of the crop, so it varies depending on time.

Table 6. Proximate composition of ligulate flowers of some wild dahlia species

\begin{tabular}{|c|c|c|c|c|c|c|c|}
\hline \multirow[t]{2}{*}{ Species } & \multicolumn{7}{|c|}{$(\%)$} \\
\hline & M & $\mathrm{DM}$ & $\mathrm{CP}$ & $\mathrm{RF}$ & RFi & $\mathrm{TC}$ & $\mathrm{A}$ \\
\hline D. brevis & $88.8 \mathrm{~h}^{*}$ & $11.2 \mathrm{~b}$ & $12.7 \mathrm{~d}$ & $3.3 \mathrm{a}$ & $11.6 \mathrm{e}$ & $65.1 \mathrm{~d}$ & $7.3 \mathrm{~b}$ \\
\hline D. merckii & $89.5 \mathrm{~g}$ & $10.5 \mathrm{c}$ & $14.8 \mathrm{~b}$ & $3.4 \mathrm{a}$ & $11.3 \mathrm{ef}$ & $64.0 \mathrm{f}$ & $6.5 \mathrm{c}$ \\
\hline D. coccinea & $85.9 \mathrm{i}$ & $14.1 \mathrm{a}$ & $13.5 \mathrm{c}$ & $2.6 \mathrm{~b}$ & $9.8 \mathrm{~g}$ & $68.6 \mathrm{a}$ & $5.5 \mathrm{~g}$ \\
\hline D. campanulata & $93.4 \mathrm{a}$ & $6.6 \mathrm{i}$ & $13.7 \mathrm{c}$ & $3.4 \mathrm{a}$ & $14.3 \mathrm{a}$ & $59.9 \mathrm{~g}$ & $8.7 \mathrm{a}$ \\
\hline \multicolumn{8}{|l|}{ D. $\times$ hortorum } \\
\hline Cherry & $89.84 \mathrm{f}$ & $10.1 \mathrm{~d}$ & $14.3 \mathrm{~b}$ & $1.5 \mathrm{e}$ & $11.2 \mathrm{ef}$ & $67.0 \mathrm{~b}$ & $5.9 \mathrm{f}$ \\
\hline Yellow & $91.0 \mathrm{c}$ & $8.9 \mathrm{~g}$ & $16.2 \mathrm{a}$ & $2.0 \mathrm{~d}$ & $10.9 \mathrm{f}$ & $64.3 \mathrm{ef}$ & $6.6 \mathrm{c}$ \\
\hline White & $90.4 \mathrm{e}$ & $9.6 \mathrm{e}$ & $13.5 \mathrm{c}$ & $2.2 \mathrm{c}$ & $12.1 \mathrm{~d}$ & $65.8 \mathrm{c}$ & $6.4 \mathrm{c}$ \\
\hline Purple & $90.5 \mathrm{~d}$ & $9.5 \mathrm{f}$ & $11.9 \mathrm{e}$ & $2.2 \mathrm{~cd}$ & $12.6 \mathrm{c}$ & $67.0 \mathrm{~b}$ & $6.2 \mathrm{e}$ \\
\hline Red & $91.4 \mathrm{~b}$ & $8.5 \mathrm{~h}$ & $13.5 \mathrm{c}$ & $2.3 \mathrm{c}$ & $13.8 \mathrm{~b}$ & $64.7 \mathrm{de}$ & $5.8 \mathrm{f}$ \\
\hline
\end{tabular}

Note: M: moisture; DM: dry matter; CP: crude protein; RF: raw fat; RFi: raw fibre; TC: total carbohydrates; A: ash. Data is expressed on dry weight basis. *Means with the same letter within columns are not statistically different according to the Tukey test $(p \leq 0.05)$ 
The CP content was higher in $D . \times$ hortorum yellow flowers $(16.2 \%)$ than in the purple flowers of the same species $(11.9 \%)$. In contrast, LaraCortés et al. (2014) report for dahlia flowers CP values between $0.8-4.0 \%$, however, they are similar to those in edible flowers of Agave salmiana and

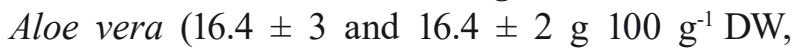
respectively) reported by Lara-Cortés et al. (2013). On the other hand, D. brevis, D. merckii and D. campanulata were the most outstanding species with respect to the RF content (3.3, 3.4 and 3.4\%, respectively), while the lowest RF percentage was for the cherry $D . \times$ hortorum $(1.5 \%)$. These results were slightly higher than those reported by LaraCortés et al. (2014) in dahlia flowers (0.5-1.6\%). Because the main component of flowers is water, the fat content in them is minimal (Fernandes et al., 2018), so they are considered a low-calorie food (with a low calorific value) (López-Cervantes et al., 2018), recommended for consumption by people with obesity (Loizzo et al., 2016; Rachkeeree et al., 2018).

The RFi content fluctuated between 9.8 and $14.3 \%$, in which $D$. campanulata stands out, followed by $D . \times$ hortorum with red flowers $(13.8 \%)$, while the lowest percentage was in D. coccinea. Similar values are reported by Lara-Cortés et al. (2013) in A. salmiana, Euphorbia radians, Arbutus xalapensis and $A$. vera $(12.7,12.6,10.4$, and 13.8 g $100 \mathrm{~g}^{-1} \mathrm{DW}$, respectively), so the dahlia species with a high RFi content could be a good alternative source of fibre to reduce the level of cholesterol (Rachkeeree et al., 2018) and help bowel evacuation (Fernandes et al., 2018).

The highest TC concentration was in D. coccinea (68.6\%), followed by $D . \times$ hortorum with cherry and purple flowers $(67.0 \%$ each), while the lowest value was presented by $D$. campanulata $(59.9 \%)$. In this regard, López-Cervantes et al. (2018) indicate a TC concentration of $60.4-68.6 \%$ in $A$. vera flowers, which indicates that $\mathrm{TC}$ are the main nutrients, representing more than $50 \%$ of total dry weight.

With respect to the presence of ash, it was the highest in D. campanulata $(8.7 \%)$, followed by $D$. brevis $(7.3 \%)$, which exceeded that in the cultivated species $D . \times$ hortorum with yellow flowers (6.6\%) by $32.2 \%$ and $10.3 \%$, respectively, while the lowest content was presented by $D$. coccinea $(5.5 \%)$. These results are similar to those indicated by Lara-Cortés et al. (2013) in the inflorescences of A. salmiana, Erythrina americana, E. radians, Hibiscus sabdariffa, A. xalapensis and A. vera (5.8,

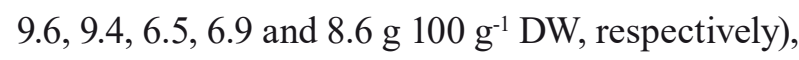
with variations that could be associated with the nutritional status of the soil, plant species and organ, and the phenological stage at harvest (Sotelo et al., 2007; Juárez-Rosete et al., 2019).

\section{CONCLUSIONS}

The results of the study are the basis for formulating the following conclusions:

1. In the present study, the ligulate flowers of the wild species $D$. coccinea were the most outstanding with regard to the concentrations of ascorbic acid, TP, TFl and antioxidant capacity; however, $D . \times$ hortorum presented the highest values of fresh weight, TSS, colour parameters and total anthocyanins.

2. Among the analysed wild species of dahlia, $D$. coccinea had the highest values of dry matter and total carbohydrates, whereas D. campanulata stood out for the highest fat content and crude fibre.

3. Intake of bioactive compounds through the incorporation of the ligulate flowers of wild species of dahlia into the diet can be an important alternative for the diversification in their use, as well as contribution to their conservation as plant genetic resources.

\section{FUNDING}

This research was financed by the Departamento de Fitotecnia at the Universidad Autónoma Chapingo (UACh).

\section{AUTHOR CONTRIBUTIONS}

E.A.R.E., M.R.G.M., J.M.M.M. and M.T.B.C.L. - designed the experiments and performed analytical measurements; E.A.R.E, O.C.A and M.T.M.D - collected data and performed analyses; M.T.M.D and O.C.A. - analysed the data and wrote the paper.

\section{CONFLICT OF INTEREST}

Authors declare no conflict of interest.

\section{REFERENCES}

Ahmad, S.S., TAHIR I., 2016. Increased oxidative stress, lipid peroxidation and protein degradation trigger senescence in Iris versicolor L. flowers. Physiol. Mol. Biol. Plants. 22(4), 507-514.

Arellano K., Herrera J., Quispe M., Espinoza C., Veliz N., Orihuela W., 2015. Evaluation of phenolic 
compounds and antioxidant capacity of three color petal cress (Tropaeolum majus L.). Rev. Soc. Quím. Perú. 81(4), 319-328.

Anónimo. 1990. Official methods of analyses. Washington, D.C. Association of Official Analytical Chemists.

Azuma, M., Onozaki T., Ichimura K., 2019. Effects of bacterial proliferation and soluble carbohydrate levels on the vase life of cut dahlia (Dahlia variabilis) Flowers. Hort. J. 88(1), 106-115.

Babarabie M., Zarei H., Varasteh F., 2016. Physiological response of Gerbera jamesonii L. cut flowers to the cola and peppermint essence. Iran. J. Plant Physiol. 6(3), 1729-1736.

Benvenuti S., Bortolotti E., Maggini R., 2016. Antioxidant power, anthocyanin content and organoleptic performance of edible flowers. Sci. Hortic. 199, 170-177.

Chen N.H., WeI S., 2017. Factors influencing consumers' attitudes towards the consumption of edible flowers. Food Qual. Prefer. 56(Part A), 93-100.

Fernandes L., Ramalhosa E., Pereira J.A., Saraiva J.A., Casal S., 2018. The unexplored potential of edible flowers lipids. Agriculture 8(10), 1-23.

Garzón G.A., Manns D.C., Riedl K., Schwartz S.J., PADIlla-ZaKour O., 2015. Identification of phenolic compounds in petals of nasturtium flowers (Tropaeolum majus) by high performance liquid chromatography coupled to mass spectrometry and determination of oxygen radical absorbance capacity (ORAC). J. Agric. Food Chem. 63(6), 111-118.

Gebremedhin H., Tesfaye B., Mohammed A., Tsegay D., 2013. Influence of preservative solutions on vase life and postharvest characteristics of rose (Rosa hybrid) cut flowers. Int. J. Biotechnol. Mol. Biol. Res. 4(8), 111-118.

Giusti M.M., Wrolstad R.E., 2001. Characterization and measurement of anthocyanins by UV-visible spectroscopy. In: Current Protocols in Food Analytical Chemistry. Wrolstad R.E., Acree T.E., An H., Decker E.A., Penner M.H., Reid D.S., Schwartz S.J., Shoemaker C.F. and Sporns P. (Eds), John Wiley \& Sons, New York, F1.2.1-F1.2.13.

Huang M., Xu Q., Deng X.X., 2014. L-Ascorbic acid metabolism during fruit development in an ascorbaterich fruit crop chestnut rose (Rosa roxburghii Tratt). J. Plant Physiol. 171(14), 1205-16.

JAGOTA S., DANi H., 1982. A new colorimetric technique for the estimation of vitamin $\mathrm{C}$ using Folin Phenol Reagent. Anal. Biochem. 127(1), 178-182.

Juárez-Rosete C.R., Aguilar-Castillo J.A., AburtoGonzález C.A., Alejo-Santiago G., 2019. Biomass production, nutritional requirement of nitrogen, phosphorus and potassium, and concentration of the nutrient solution in oregano. Rev. Chapingo Ser. Hortic. 25(1), 17-28.

Kaisoon O., Siriamornpun S., Weerapreeyakul N., MeEso N., 2011. Phenolic compounds and antioxidant activities of edible flowers from Thailand. J. Funct. Foods. 3(2), 88-99.

Lara-Cortés E., Martín-Belloso O., Osorio-Díaz P., Barrera-Necha L.L., SÁnchez-López J.A., Bautista-Baños S., 2014. Antioxidant capacity, nutritional and functional composition of edible Dahlia flowers. Rev. Chapingo Ser. Hortic. 20(1), 101-116.

Lara-Cortés E., Osorio-Díaz P., JimÉnez-Aparicio A., Bautista-Baños S., 2013. Nutritional content, functional properties and conservation of edible flowers. Review. Arch. Latinoam. Nutr. 63(3), $197-$ 208.

Lara-Cortés E., Troncoso-Rojas R., HernándezLóPEz M., BAUTISTA-BAÑos S., 2016. Evaluation of the antimicrobial activity of cinnamaldehyde in the preservation of edible dahlia flowers, under different storage conditions. Rev. Chapingo Ser. Hortic. 22(3), 177-189.

Lee J.H., LeE H.J., Choung M.G., 2009. Anthocyanin compositions and biological activities from the red petals of Korean edible rose (Rosa hybrida cv. Noblered). Food Chem. 129(2), 272-278.

Li X., Lu M., Tang D., Shi Y., 2015. Composition of carotenoids and flavonoids in narcissus cultivars and their relationship with flower color. PLoS ONE, 10(1), e0142074.

LiU L., Zhang L.Y., WANG S.L., NiU X.Y., 2016. Analysis of anthocyanins and flavonols in petals of 10 Rhododendron species from the Sygera Mountains in Southeast Tibet. Plant Physiol. Biochem. 104, 250 256.

Loizzo M.R., Pugliese A., Bonesi M., Tenuta M.C., Menichini F., XIAO J., ET AL., 2016. Edible flowers: a rich source of phytochemicals with antioxidant and hypoglycemic properties. J. Agric. Food Chem. 64(12), 2467-2474.

López-Cervantes J., Sánchez-Machado D.I., CruzFlores P., Mariscal-Domínguez M.F., Servín De La Mora-López G., ET AL., 2018. Antioxidant capacity, proximate composition, and lipid constituents of Aloe vera flowers. J. Appl. Res. Med. Aromat. Plants. 10, 93-98.

MlceK J., Rop O., 2011. Fresh edible flowers of ornamental plants - A new source of nutraceutical foods. Trends Food Sci. Technol. 22(10), 561-569.

NaVArro-González I., GonzÁlez-Barrio R., GarciaValverde V., Bautista-Ortín A.B., Periago M.J., 2015. Nutritional composition and antioxidant capacity in edible flowers: Characterisation of phenolic compounds by HPLC-DAD-ESI/MSn. Int. J. Mol. Sci. 16(1), 805-822.

Ohno S., Deguchi A., Hosokawa M., Tatsuzawa F., Dor M., 2013. A basic helix-loop-helix transcription factor DvIVS determines flower color intensity in cyanic dahlia cultivars. Planta 238(2), 331-343.

Ozgen M., Reese R.N., Tulio A.Z., Miller A.R., ScheErens J.C., 2006. Modified 2,2-Azino-bis-3- 
ethylbenzothiazoline-6-sulfonic acid (ABTS) method to measure antioxidant capacity of selected small fruits and comparison to ferric reducing antioxidant power (FRAP) and 2,20-diphenyl-1-picrylhydrazyl (DPPH) methods. J. Agric. Food Chem. 54(4), 11511157.

Pires T.G.S.P., Dias M.I., Barros L., Galhelha R.G., Alves M.J., OliveIRa M.B.P.P., ET AL., 2018. Edible flowers as sources of phenolic compounds with bioactive potential. Food Res. Int. 105, 580-588.

Rachkeeree A., Kantadoung K., Suksathan R., Puangpradab R., Page P.A., Sommano S.R., 2018. Nutritional compositions and phytochemical properties of the edible flowers from selected zingiberaceae found in Thailand. Front. Nutr. 5(3), $1-10$.

Ren P.J., Jin X., Liao W.B., Wang M., Niu L.J., Li X.P., ET AL. 2017. Effect of hydrogen-rich water on vase life and quality of cut lily and rose flowers. Hortic. Environ. Biotechnol. 58(6), 576-584.

Rop O., Mlcek J., Jurikova T., Neugebauerova J., VABKova J., 2012. Edible flowers - A new promising source of mineral elements in human nutrition. Molecules 17(6), 6672-6683.

SotelO, A., López-Garcia S., Basurto-PeÑa F., 2007. Content of nutrient and antinutrient in edible flowers of wild plants in Mexico. Plant Foods Hum. Nutr. 62(3), 133-138.
Waterman P.G., Mole S., 1994. Methods in Ecology. Analysis of Phenolic Plant Metabolites. Blackwell Scientific Publications, Oxford, USA.

Yang E., Kang H., Kim C., PAK C.H., 2014. Dependence of the color appearance of some flowers on illumination. Color Res. Appl. 39(1), 28-36.

Younis A., Anjum S., Riaz A., Hameed M., Tariq U., Ahsan M., 2014. Production of quality dahlia (Dahlia variabilis cv. Redskin) flowers by efficient nutrients management running title: plant nutrition impacts on dahlia quality. Am. Eurasian J. Agric. Environ. Sci. 14(2), 137-142.

Zeng Y., Deng M., Zhencheng LV., Peng Y., 2014. Evaluation of antioxidant activities of extracts from 19 Chinese edible flowers. SpringerPlus 3(1), 315.

Zhang C., Fu J.X., Wang Y.J., GaO S.L., Du D.N., WU F., ET AL., 2015. Glucose supply improves petal coloration and anthocyanin biosynthesis in Paeonia suffruticosa Luoyang Hong' cut flowers. Postharvest Biol. Technol. 101, 73-81.

Zhao D.Q., TaO J., Han C.X., Ge J.T., 2012. Flower color diversity revealed by differential expression of flavonoid biosynthetic genes and flavonoid accumulation in herbaceous peony (Paeonia lactiflora Pall.). Mol. Biol. Rep. 39(12), 11263-11275.

Received May 1, 2019; accepted September 17, 2019 